\title{
A Role of Job Involvement and Organizational Effectiveness with Reference to Private Sector Banks in Tirupur
}

\author{
G. Kalpana and Dr.A. Dharmaraj
}

\begin{abstract}
A Study on private sector banks in tirupur city is to analyze the impact of employee's contribution on organizational effectiveness. The results obtained will be helpful to know about the expectations of the employees and to implement the development strategies of human resource. From the population of 250 a sample of 200 respondents was taken on random basis. A structured questionnaire was prepared and circulated among the employees and their feedback was obtained. The secondary data was collected with the help of books, internet and intranet. From the data obtained analysis is carried out with the help of statistical tools. Based on the information obtained current level of employee's contribution is known and suggestions are given to develop the contribution level.
\end{abstract}

\section{INTRODUCTION}

SUCCESS of an organisation depends on various factors. Organisational effectiveness is considered to be an important for the success of the organisation. Organisational effectiveness means, the extent to which the organisation fulfils its goals or objectives. The organisation effectiveness is the utilization of organisational resources, namely, human, capital, technology, etc in an effective, sensible and deliberate manner for the purpose of achieving its objectives or goals by taking care not only the share holders but also the stake holders. It producing a desired effect or productivity without waste. Organisational effectiveness can also be stated as the integration of the organisation goals and employees. There are various factors which influence the effectiveness of the organisation, namely, employee motivation, commitment, environment, culture, work diversity, job satisfaction, etc. one of the important factor is job involvement which radically affects the effectiveness of the organisation.

\section{REVIEW OF LITERATURE}

Robert J. Vandenberg(2002) his study results reveals that the higher the job involvement influence the organizational effectiveness. Kahn (1990) have found that the employees with high job involvement will put more effort towards achieving organizational goals. Biswas, U.N.. (1998). Perception of organisation effectiveness has a significant

G. Kalpana, Research Scholar, Management, Karpagam Academy of Higher Education, Coimbatore.

Dr.A. Dharmaraj, Associate Professor, Department of Management, Karpagam Academy of Higher Education, Coimbatore.

DOI: 10.9756/IJRAS.8151 influence with job involvement of the employees. Has found that job involvement and organisational effectiveness are positively related. Joby Jose and N. Panchanatham (2014) the job involvement has a great impact in accomplishing both individual and the organizational goals. If the employee perceives negative reactions from an organization they will show low involvement in their job. Thus, Job involvement of the employees will have great impact in the overall organizations effectiveness. Bijaya Kumar Sundaray (2011) found that employee engagement induces a positive attitude among the employees towards the organization effectiveness. Andreadis, N. (2009) There is association between job involvement and organizational effectiveness by which job involvement becomes predicator of effectiveness of organization success. Most organizational effectiveness is linked to job involvement and organizational commitment where people do feel with the job.

Wim J. Nijhof, Margriet J. de Jong, Gijs Beukhof argues that Contribution of employees can be an important instrument for improving the performance of organizational effectiveness. It is related to personal, job and organizational characteristics. The study intends to explore some important relations between the characteristics of commitment and organizational effects. Between commitment and the level of the organization the most important relations are a better communication and less illness; at the level of the individual employee the commitment to change and to take part very actively in change processes, bringing up new ideas, is important.

Paul and Anantharaman in their study in India "Influence of HRM practices on organizational effectiveness. A study among software professionals in India", reveals that HRM practices such as employee-friendly work environment, career development, development oriented appraisal, and comprehensive training show a significant positive relationship with organizational effectiveness.

Rajendran Muthuveloo and Raduan Che Rose (2005) Organisational effectiveness is a subset of employee commitment, which is comprised of work commitment, career commitment and organisational commitment. Organisational commitment, in turn, can be subdivided into affective commitment, continuance commitment and normative commitment. As a combination of both attitudinal and behavioural approaches, organizational commitment is defined as employees' acceptance, involvement and dedication (AID) towards achieving the organisation's goals. It is the willingness of employees to accept organisational values, and 
goals, and to work towards achieving these; to be fully involved, and participate, in all the activities.

Griffin and Moorhead (2009) Reward system is composed of all organizational components, which include people, processes, rules and procedures, together with the decisionmaking activities, which involved the process in allocating compensation and benefits to employees, in exchange for their contribution to the organization. The main purpose of reward system is to attract, retain and motivate qualified employees. This help to maintain the equality and fairness of rewards being offered towards the employees, which are primarily based on their performance and contributions to the company. There are different types of rewards, which help in order to attract qualified candidates and retain useful and valuable employees in the company. These include: base pay, incentive systems, indirect compensation, perquisites and awards.

\section{SCOPE OF THE STUDY}

- The study aims to analyze the effectiveness of the training and development program.

- The study explores the views expressed by the Respondents about the working conditions of the organization.

- The study would reveal the gap between the employee expectation and banks's deliverance.

- The study helps to analyze the overall performance of employees.

- The findings of this study help the company to implement the expectations from the employees.

\section{OBJectives OF THE STUDY}

- To identify the contribution level of employees related to organizational effectiveness in private sector banks in tirupur city .

- To find out the factors causing motivation at work place.

- To know the satisfaction level on monetary policies in the organization.
- To identify the working condition factors influencing organizational effectiveness.

\section{Limitations OF THE STUdY}

- Some employees were having little difficulty in expressing their views which are related to job.

- Accuracy of the study is purely based on the information as given by the respondents.

- The finding of study may not be free from employee's opinion.

\section{Research Methodology}

The purpose of this study was to analyze the factors which influence the overall performance of the organization and to concentrate on the factor which has to be improving for increasing the organizational effectiveness. A Research design is a framework on which the research is conducted. All the activities of a research are done by laying the research design as the platform. In this survey descriptive research design has been used. Descriptive research includes surveys and factfinding enquiries of different kinds. The major purpose of this research is description of state of affairs as it exists at present. Sample Units based on Employee's in private sector bank's , It refers to the number if items to be selected from the universe to constitute a sample. Here 200 employees were selected as size of sample. The data was collected with primary and secondary data collection methods. The data which are collected afresh for the first time and thus happen to be original in character is called primary data. The primary data was collected from the employees of private sector banks in tirupur city, through a direct structured questionnaire. Respondent has filled the questionnaire. The data which have already been collected and analyzed by someone else is called secondary data. The secondary data was used mainly to support primary data. Company profiles, websites, magazines, articles were used widely. To analysis and interpret the collected data the following statistical tools were used. Correlation Analysis. ANOVA. Regression.

\section{Correlation Analysis}

Whether Qualification Associate with Motivation and Compensational Factors

\begin{tabular}{|c|c|c|c|c|c|}
\hline & CORRELATIONS & Qualification & $\begin{array}{c}\text { Motivation } \\
\text { level }\end{array}$ & $\begin{array}{c}\text { Monetary } \\
\text { Benefits }\end{array}$ & Pay package \\
\hline \multirow[t]{3}{*}{ Qualification } & Pearson Correlation & 1 & $.897^{* *}$ & $.839^{* *}$ & $.907^{* *}$ \\
\hline & Sig. (2-tailed) & & .000 & .000 & .000 \\
\hline & $\mathrm{N}$ & 200 & 200 & 200 & 200 \\
\hline \multirow[t]{3}{*}{ Motivation level } & Pearson Correlation & $.897^{* *}$ & 1 & $.908^{* *}$ & $.931^{* *}$ \\
\hline & Sig. (2-tailed) & .000 & & .000 & .000 \\
\hline & $\mathrm{N}$ & 200 & 200 & 200 & 200 \\
\hline \multirow[t]{3}{*}{ Monetary benefits } & Pearson Correlation & $.839^{* *}$ & $.908^{* *}$ & 1 & $.934^{* * *}$ \\
\hline & Sig. (2-tailed) & .000 & .000 & & .000 \\
\hline & $\mathrm{N}$ & 200 & 200 & 200 & 200 \\
\hline \multirow[t]{3}{*}{ Pay package } & Pearson Correlation & $.907^{* *}$ & $.931^{* *}$ & $.934^{* *}$ & 1 \\
\hline & Sig. (2-tailed) & .000 & .000 & .000 & \\
\hline & $\mathrm{N}$ & 200 & 200 & 200 & 200 \\
\hline
\end{tabular}

**. Correlation is significant at the 0.01 level (2-tailed).

Null Hypothesis $(\mathrm{H} 0)=$ There is no association between
Qualification and Motivation and Compensational factors. Alternative Hypothesis (Ha) $=$ There is an between Qualification and Motivation and Compensational factors. 
Inference From the above table, it infers that, Motivation and Compensational factor is positively associated with

qualification. So, that Alternative Hypothesis (Ha) is accepted.

Whether Qualification Associate with Working Environment and Morale Factors

\begin{tabular}{|l|l|l|l|l|l|l|}
\hline & & $\begin{array}{c}\text { Working } \\
\text { Conditions }\end{array}$ & $\begin{array}{c}\text { Work life } \\
\text { Balance }\end{array}$ & $\begin{array}{c}\text { Work } \\
\text { Happily }\end{array}$ & Relationship & $\begin{array}{c}\text { Supportive } \\
\text { Management }\end{array}$ \\
\hline \multirow{5}{*}{ w.conditions } & Pearson Correlation & 1 & $.789^{* *}$ & $.877^{* *}$ & $.943^{* *}$ & $.867^{* *}$ \\
\cline { 2 - 7 } & Sig. (2-tailed) & & .000 & .000 & .000 & .000 \\
\cline { 2 - 7 } & $\mathrm{N}$ & 200 & 200 & 200 & 200 & 200 \\
\hline \multirow{5}{*}{ W.L.balance } & Pearson Correlation & $.789^{* *}$ & 1 & $.676^{* *}$ & $.767^{* *}$ & $.711^{* *}$ \\
\cline { 2 - 7 } & Sig. (2-tailed) & .000 & & .000 & .000 & .000 \\
\cline { 2 - 7 } & $\mathrm{N}$ & 200 & 200 & 200 & 200 & 200 \\
\hline relationship & Pearson Correlation & $.877^{* *}$ & $.676^{* *}$ & 1 & $.876^{* *}$ & $.856^{* *}$ \\
\cline { 2 - 7 } & Sig. (2-tailed) & .000 & .000 & & .000 & .000 \\
\cline { 2 - 7 } & N & 200 & 200 & 200 & 200 & 200 \\
\cline { 2 - 7 } & Pearson Correlation & $.943^{* *}$ & $.767^{* *}$ & $.876^{* *}$ & 1 & $.831^{* *}$ \\
\cline { 2 - 7 } & Sig. (2-tailed) & .000 & .000 & .000 & & .000 \\
\hline \multirow{5}{*}{ S.management } & Pearson Correlation & $.867^{* *}$ & $.711^{* *}$ & $.856^{* *}$ & $.831^{* *}$ & 1 \\
\cline { 2 - 7 } & Sig. (2-tailed) & .000 & .000 & .000 & .000 & 200 \\
\cline { 2 - 7 } & N & 200 & 200 & 200 & 200 & 200 \\
\hline
\end{tabular}

**. Correlation is significant at the 0.01 level (2-tailed).

Null Hypothesis(H0) = There is no association between Working Environment and Morale factors.

Alternative Hypothesis $(\mathrm{Ha})=$ There is an association between Working Environment and Morale factors.

\section{Inference}

From the above table, it infers that, Morale factor is positively associated with Working Environment. So, that Alternative Hypothesis (Ha) is accepted. From the above table, it infers that, qualification is positively associated with monetary benefits. So, that Alternative Hypothesis (Ha) is accepted. From the above table, it infers that motivation level is positively associated with pay package. So, that Alternative Hypothesis (Ha) is accepted. From the above table, it infers that work life balance is positively associated with working conditions. So, that Alternative Hypothesis (Ha) is accepted. From the above table, it infers that work happily is positively associated with work life balance. So, that Alternative Hypothesis (Ha) is accepted. From the above table, it infers that relationship is positively associated with supportive management. So, that Alternative Hypothesis (Ha) is accepted. From the above table, it infers that motivation level is positively associated with monetary benefits. So, that Alternative Hypothesis (Ha) is accepted. ANOVA

Whether Same Opinion between Experience and Working Environment

\begin{tabular}{|ll|l|l|l|l|l|}
\hline \multicolumn{2}{|c|}{ EXPERIENCE } & Sun of Square & Diff & Mean Square & \multicolumn{1}{c|}{$F$} & Sig. \\
\hline Safety Measures & Between Groups & 318.348 & 4 & 79.587 & 301.190 & .000 \\
& Within Groups & 51.527 & 195 & .264 & & \\
& Total & 369.875 & 199 & & & \\
\hline Work Load & Between Groups & 329.333 & 4 & 82.333 & 396.008 & .000 \\
& Within Groups & 40.542 & 195 & .208 & & \\
& Total & 369.875 & 199 & & & \\
\hline Resolution & Between Groups & 332.375 & 4 & 83.094 & 432.088 & .000 \\
& Within Groups & 37.500 & 195 & .192 & & \\
& Total & 369.875 & 199 & & & \\
& & & & & & \\
\hline WorkLife Balance & Between Groups & 247.481 & 4 & 61.870 & 98.572 & .000 \\
& Within Groups & 122.394 & 195 & .628 & & \\
& Total & 369.875 & 199 & & & \\
\hline
\end{tabular}

Hypothesis (H0) = There is no on an average same opinion between Experience and Working Environment factors. Alternative Hypothesis $(\mathrm{Ha})=$ There is an average same opinion between Experience and Working Environment factors. Inference From the above table, it knows that, difference in Experience have same opinion on Safety measures, Work place/ Working conditions, resolution and Work life balance. So, in these factors, Alternate Hypothesis (Ha) is accepted. 
ANOVA (Same Opinion between Experience and Facilities and Welfare Measures)

\begin{tabular}{|l|l|l|l|l|c|c|}
\hline & EXPERIENCE & Sum of Squares & Diff & Mean Square & $F$ & Sig. \\
\hline \multirow{5}{*}{ Facilities } & Between Groups & 278.529 & 4 & 69.632 & 480.378 & .000 \\
\cline { 2 - 8 } & Within Groups & 28.266 & 195 & .145 & & \\
\cline { 2 - 8 } & Total & 306.795 & 199 & & & \\
\hline Safety measures & Between Groups & 273.602 & 4 & 68.401 & 343.963 & .000 \\
\cline { 2 - 8 } & Within Groups & 38.778 & 195 & .199 & & \\
\cline { 2 - 8 } & Total & 312.380 & 199 & & & \\
\hline \multirow{5}{*}{ Health and security } & Between Groups & 286.650 & 4 & 71.662 & 489.804 & .000 \\
\cline { 2 - 8 } & Within Groups & 28.530 & 195 & .146 & & \\
\cline { 2 - 8 } & Total & 315.180 & 199 & & & \\
\hline \multirow{5}{*}{ w.benefits } & Between Groups & 142.392 & 4 & 35.598 & 528.773 & .000 \\
\cline { 2 - 8 } & Within Groups & 13.128 & 195 & .067 & & \\
\cline { 2 - 8 } & Total & 155.520 & 199 & & & \\
\hline
\end{tabular}

Null Hypothesis $(\mathrm{H} 0)=$ There is no on an average same opinion between Experience and Facilities and Welfare measures. Alternative Hypothesis $(\mathrm{Ha})=$ There is an average same opinion between Experience and Facilities and Welfare measures. Inference From the above table, it knows that, difference in Experience have same opinion on Security measures and Facilities and welfare measures. So, in these factors, Alternate Hypothesis (Ha) is accepted.

\section{REGRESSION}

Whether Independent Variable Associate with Dependent Variable

\begin{tabular}{|l|c|l|}
\hline Model & $R$ & RSquare \\
\hline 1 & $.951^{2}$ & .905 \\
\hline
\end{tabular}

From the above table, independent Variables Influence Dependent Variable.

\begin{tabular}{|l|l|c|c|c|c|c|}
\hline \multicolumn{2}{|l|}{} & Sum of Squares & $D f$ & Mean Square & $F$ & Sig. \\
\hline & Regression & 170.419 & 4 & 42.605 & 462.168 & $.000^{\mathrm{a}}$ \\
\cline { 2 - 7 } & 17.976 & 195 & .092 & & \\
\hline Residual & 188.395 & 199 & & & \\
\hline Total & a. Predictors: (Constant), motivationlevel, monetary benefits, pay package, correct recognition \\
\hline
\end{tabular} $\begin{aligned} & \text { b. Dependent Variable: } \\
& \text { working conditions }\end{aligned}$

\begin{tabular}{|l|r|r|r|}
\hline & Standardized coefficients & $t$ & \multicolumn{1}{|c|}{ Sig } \\
\cline { 2 - 2 } & Beta & 4.554 & .000 \\
Correct recognition & -.147 & -2.139 & .034 \\
Job security & .052 & .645 & .520 \\
Monetary benefits & .428 & 4.782 & .000 \\
Motivation level & .622 & 8.593 & .000 \\
\hline
\end{tabular}

Null Hypothesis $(\mathrm{H} 0)=$ There is no association between Correct recognition, Job security, Monetary Benefits, Motivation Level and Working conditions. Alternative Hypothesis (Ha) = There is an association between Correct recognition, Job security, Monetary Benefits, Motivation Level and Working conditions. Inference From the above table, it infers that, Motivation and compensation factors of Organization are positively influence Working Environment. Hence, Alternative Hypothesis (Ha) is accepted.

\section{FINDINGS}

\section{Correlation Analysis}

It is found that, there is an association between qualification and compensational factors. It shows that, there is an association between motivation level and compensational factors. The study reveals that, there is an association between Work life balance and Working conditions factors. It is found that, there is an association between working environment 
factors. The study shows that, there is an association between Morale factors. It is found that, there is an association between motivation and monetary benefits.

\section{ANOVA}

It is found that, there is an average same opinion between Experience and Safety measures. The analysis shows that, there is an average same opinion between Experience and Work load. It reveals that, there is an average same opinion between experience and Work life balance. The study helps to find that, there is an average same opinion between Welfare measures and Experience. It is found that, there is an average same opinion between Experience and Resolution.

\section{Regression}

It is found that, Independent Variables like Monetary benefits, Motivation level, Correct recognition are positively influenced by Working conditions. It is found that, Independent Variables like Job security, Monetary benefits, Correct recognition are positively influenced by Working conditions.

\section{SugGeStions}

The motivation and compensational benefits may be increase the satisfaction level of the employees in the Organization. The company may improve Employees morale at work place by the way of increasing smooth relationship between workers and superiors. The company may take necessary steps to increase the welfare facilities and to satisfy the workers. The Company may take steps to improve the employee's skills by giving personality training program. Organization should follow performance appraisal periodically and rewards should be given frequently for making employees fully engaged in their work.

\section{CONCLUSION}

In order to improve the performance and productivity of workers it is necessary to increase the contribution level of the employee and provide the facilities required. This study highlights some factors such as Training and Development, Working environment and conditions, Motivation, Rewards, Compensation system, Employee welfare and Safety measures. From this study the researcher understand that private sector banks is providing good Working measures and Motivation and Compensational Benefits and are having high level of satisfaction among them. The researcher has tried to give some suggestion for the improvement of Organizational Effectiveness.

\section{REFERENCES}

[1] A. Bhatia, G. Deep and S. Sachdeva, "Analyzing the role of job involvement on organisational effectiveness: An empirical study among the employees of Punjab national bank", International journal of Computing \& Business research, Pp. 2229-6166, 2012.

[2] N. Andreadis, "Learning and organizational effectiveness: A systems perspective”, Performance Improvement, Vol. 48, No. 1, Pp. 5-11, 2009.

[3] B.K. Sundaray, "Employee engagement: a driver of organizational effectiveness”, European Journal of Business and Management, Vol. 3, No. 8, Pp. 53-59, 2011.

[4] U.N. Biswas, "Life-Style Stressors, Organisational Commitment, Job Involvement and Perceived Organisational Effectiveness across Job
Levels”, Indian Journal of Industrial Relations, Vol. 34, No. 1, Pp. 55-72, 1998.

[5] J. Jose and N. Panchanatham, "Influence of Job Satisfaction and Organizational Commitment on Job Involvement towards Organizational Effectiveness", Indian Journal of Applied Research, Vol. 4, No. 1, 2014.

[6] W.A. Kahn, "Psychological conditions of personal engagement and disengagement at work”, Academy of management journal, Vol. 33, No. 4, Pp. 692-724, 1990.

[7] M. Judeh, "An examination of the effect of employee involvement on teamwork effectiveness: An empirical study", International Journal of Business and Management, Vol. 6, No. 9, Pp. 202, 2011.

[8] S.J. Mudiappasamy Devadoss and R. Muth, "Power, involvement and organisational effectiveness in higher education", Higher education, Vol. 13, No. 4.

[9] A. Rangone, "Linking organizational effectiveness, key success factors and performance measures: an analytical framework", Management Accounting Research, Vol. 8, No. 2, Pp. 207-219, 1997. 